\title{
"A EPOPEIA DA DECADÊNCIA":* UM ESTUDO SOBRE O ESSAI SUR L'INÉGALITÉ DES RACES HUMAINES (1853-1855), DE ARTHUR DE GOBINEAU
}

Helga da Cunha Gahyva

\section{Introdução}

O objetivo deste artigo é refletir sobre uma obra bastante comentada, porém relativamente pouco estudada: ${ }^{1}$ o Essai sur l'inégalité des races humaines ${ }^{2}$ (Gobineau 1983), do diplomata, escritor e escultor francês Arthur de Gobineau. À época de seu lançamento, o livro despertou parca atenção mas, na virada do século XIX para o XX, ele foi alçado à condição de peça fundadora do moderno pensamento sobre as raças, sendo doravante rotulado como "o poço envenenado donde brotou toda a teorização racista posterior" (Banton 1979:53).

Equivocam-se os que atribuem à obra repercussão imediata (Gay 2001:82; Azevedo 1990:25), mas não se pode dizer que o diplomata tenha precocemente se conformado com o pífio destaque conferido a seu estudo sobre as raças. Em 1878, ele relatava a D. Pedro II seus esforços em trazer à tona uma segunda edição do tratado (Raeders 1938:263). Suas tentativas revelaram-se infrutíferas: em 1882, ano de seu falecimento, ele resignadamente afirmava ao monarca brasileiro "[...] que nem Plon nem nenhum outro editor quis fazer uma segunda edição do Essai sur l'inégalité des races" (Raeders 1938:368). ${ }^{3}$

A "(re)descoberta" póstuma absorveu o Essai em uma discussão na qual o conceito de raça vinha já impregnado de sugestões fenotípicas. Em oposição à estabelecida versão exclusivamente biologizada da reflexão de Gobineau, pretende-se, neste artigo, revelar que não se encontra no tratado sobre as raças uma visão "moderna" da ideia de raça. Sob o léxico racial, seu autor reatualiza uma reflexão característica da perspectiva germanista elaborada no âmbito da Querela das duas raças. Como se verá mais adiante, a nobreza litigante de fins do século XVII e princípios do XVIII compreendia as supostas distinções originárias entre as gentes a partir do conceito de linhagem. 
Não é ambição deste trabalho retomar o caminho que tornou o Essai peça de destaque na história do pensamento racialista. ${ }^{4} \mathrm{O}$ sucesso da obra, em fins do século XIX, submeteu-se, evidentemente, às demandas próprias a um período pródigo em interpretar as interações humanas segundo um elemento de natureza pretensamente biológica: a raça. Por essa época, o paradigma das ciências naturais tornava-se hegemônico, e grande parcela da intelectualidade do fin-de-siècle conferia à ideia de raça relativa autonomia conceitual, que lhe foi paulatinamente atribuída no desenrolar da segunda metade do século XIX.

Ainda assim, não foi sem obstáculos o caminho que conferiu notoriedade ao tratado de Gobineau. Pouco lido em sua França natal, o livro conquistou parcela do público alemão. Em seus últimos anos de vida, o diplomata francês tornou-se amigo do casal Wagner, com quem chegou a passar duas temporadas em Bayreuth. Após seu falecimento, Ludwig Schemann, jovem ligado ao círculo wagneriano que conhecera em sua segunda temporada teutônica, tomou para si a tarefa de resgatar do esquecimento o nome de Gobineau. Neste esforço, a filosofia da história do escritor francês, marcadamente pessimista e nostálgica, transformou-se no elogio às virtudes germânicas e ao papel de destaque que caberia à Alemanha no concerto das nações. ${ }^{5}$

Na França, a fresca lembrança da Guerra Franco-Prussiana deixava pouco espaço para um autor a quem fora posteriormente atribuído um selo made in Germany (Eugene 1998:213). Não à toa, Charles Maurras, um dos líderes da Ação Francesa, foi antes crítico do que apreciador das ideias de Gobineau. Apenas durante a Segunda Guerra Mundial os entusiastas de Vichy fizeram-se herdeiros de Gobineau, empenhados em resgatar definitivamente para seu país de origem o talento de um "deliberadamente ignorado [...] gênio premonitório" (Rouault 1943:14). Sob a Ocupação, a conexão que Maurras fizera no princípio do século, a título de denúncia, entre gobinismo e germanismo (Taguieff 2002: 79-80) fora retomada na perspectiva de uma reavaliação positiva do racismo: ao atribuir a Gobineau a paternidade da ideia, o racismo tornava-se um fenômeno nacional francês. ${ }^{6}$ Os rumos da história relativamente recente do século XX foram bem-sucedidos em sua intenção de vincular o Essai à experiência nazista; deste então, o nome do diplomata tornou-se praticamente impublicável.

Em suma, finda a Segunda Guerra, cristalizou-se uma interpretação segundo a qual o Essai teria sido um dos principais marcos teóricos da voga racialista característica da transição do século XIX para o XX. Especialmente no Brasil, país no qual ele ocupou a representação diplomática durante os anos de 1869 e 1870, suas teses teriam ecoado entre aqueles intelectuais que se propunham a discutir a questão racial no âmbito do esforço de construção da nação, submersos nos dilemas em torno do regime de trabalho servil e das crescentes demandas republicanas. 


\section{As raças possíveis}

Cumpre lembrar que nem sempre raça significou um conjunto de caracteres físicos transmitidos hereditariamente, ao qual corresponderia um conjunto de disposições morais - a raça-espécie (Remi-Giraud 2003:203-21). Nos dicionários do século XVIII, o vocábulo designa, em primeiro lugar, a história das famílias consideradas na sucessão de suas gerações — trata-se de uma concepção de raça-linhagem ${ }^{7}$ segundo a qual "as diferenças entre as raças derivavam das circunstâncias da sua história e, embora se mantivessem através das gerações, não eram fixas" (Banton 1979:29). A acepção hereditária não estava ausente do vernáculo, mas era atribuída, fundamentalmente, aos animais irracionais.

Linhagem engloba três ideias que hoje se apresentam de modo relativamente independente: nação, classe social e raça. Defendo a hipótese segundo a qual a construção teórica de Gobineau em torno daquilo que ele julgava ser sua contribuição na direção da definição de uma ideia clara e distinta de raça não se divorcia da noção de linhagem, própria de meados do século XVIII, e enfraquecida no desenrolar da centúria seguinte. A reflexão gobiniana é herdeira de uma tradição intelectual imersa na tensão conceitual expressa acima, segundo a qual a nobreza era uma nação à parte, composta por uma determinada classe social e cujas características morais transmitiamse geracionalmente - ela possuía linhagem. Gobineau constrói sua crítica à sociedade moderna sob essa rubrica. Tateando uma noção biológica de raça-espécie, ele mantém-se próximo a uma noção de raça-linhagem. ${ }^{8}$

A interdependência conceitual subjacente à linhagem confere novo sentido ao Essai, desanuviando uma gama de supostos paradoxos que só adquire sentido quando se analisa a obra como um esforço na progressiva definição de um conceito de raça-espécie. Mas o foco no tema familiar ganha significado caso se considere que o tema central do tratado não é o elogio à raça, mas a crítica à democracia.

As primeiras formulações que versam sobre um princípio de incomunicabilidade entre as gentes, que se transmite geracionalmente, datam da já citada Querela das duas raças, embate político que opôs germanistas a romanistas. A digressão à polêmica abre novas frentes para a compreensão do conceito de raça particular à ficção metodológica de Gobineau, imbuído de sugestões esboçadas pelo "feudalismo" do século XVIII — aqui representado pelo conde Henri de Boulainvilliers, porta-voz do partido germanista. Nesta chave, o autor do Essai seria o derradeiro representante de um modo de pensar as diferenças entre os homens que está na origem da ideia atual de raça: hoje cultural, ontem biológica, antes de ontem familiar. 
Boulainvilliers retomava uma proposição esboçada por François Hotman, em 1574. Em reação às determinações do Concílio de Trento, o protestante Hotman afirmava que a população francesa descendia dos germanos, e não dos romanos (Foucault 2002:142). Seu objetivo explícito era estabelecer um elo originário entre seus patrícios e a Alemanha reformada. Boulainvilliers tem outras preocupações: sua Histoire de l'ancien gouvernement de la France resgatava as controvérsias em torno das origens da população francesa com o intuito de reivindicar uma origem ariana exclusiva à nobreza (Boulainvilliers 1727). A qualidade de descendente dos conquistadores francos garantia-lhe um conjunto de prerrogativas que vinham sendo usurpadas no processo de consolidação do Estado nacional francês. Neste sentido, sua obra tinha como objetivo reivindicar a permanência de privilégios que, por direito, pertenceriam à nobreza francesa.

A reação germanista representava os interesses de setores da nobreza ameaçados tanto pela crescente concentração de poder nas mãos do monarca, quanto pelos cada vez mais frequentes processos de enobrecimento de populações plebeias. No primeiro caso, a desvalorização da nobreza provincial em face da nobreza de corte, característica do processo de centralização real, estabelecia uma distinção entre iguais, contrariando as leis fundamentais do reino que, alegavam os querelantes, asseguravam que rei e nobreza deveriam se relacionar na qualidade de primus inter paris. No segundo, os constantes processos de enobrecimento da população plebeia introduziam uma igualdade entre diferentes, contrariando, mais uma vez, os direitos históricos da nobreza (Furet 1982:175; Seillière 1903:XIV-XV; Thierry 1840:54). Se apenas parcela do povo francês conta com uma origem franca, sob a pretensa ideia de nacionalidade oculta-se uma divisão fundamental. De um lado, uma aristocracia descendente dos antigos guerreiros arianos; de outro, uma população composta pela mistura das mais variadas raças: romanos, gauleses etc. Estas demais categorias sociais, inferiores, não deveriam ser admitidas no governo da nação, pois apenas a descendência franca reservava aos verdadeiros nobres o exercício do domínio público. O partido germanista evocava as "leis fundamentais do reino" para cindir a nacionalidade e justificar a permanência de uma nação transterritorial com leis próprias: a nobreza (Foucault 2002:169). Em suma, para o nobre litigante um título nobiliárquico impunha um conjunto de disposições societárias que passava ao largo das determinações da pena real. As qualidades próprias à nobreza reproduziam-se geracionalmente, pressupondo o pertencimento à determinada linhagem.

A Revolução Francesa derrotou as pretensões do germanismo à Boulainvilliers (Seillière 1903:XIX; Thierry 1840:104). Nos momentos imediatamente 
anteriores ao evento de 1789, parte expressiva da nobreza aceitara a versão do Abade Mably quanto à real gênese dos franceses: a origem germânica era agora estendida ao Terceiro Estado. A ficção histórica do publicista prérevolucionário propunha a reconciliação nacional no seio do germanismo, exemplificando um viés dessa ideologia que renunciou ao tema da linhagem, da raça, daquelas qualidades transmitidas no seio das nobres famílias (Mably 1797:110-111). Não há dúvida de que permanece um princípio de exclusão, pois apenas aquelas duas classes são aptas para lidar com a coisa pública (Furet 1982:179; Thierry 184:101). Ainda assim, Mably representa um germanismo sedento de negociação. A burguesia tornara-se herdeira comum daquele patrimônio conferido pela descendência germânica.

Se a versão do abade prevaleceu sobre a de Boulainvilliers, nunca deixou de existir certo germanismo dissidente que se recusava a dialogar com os novos tempos. Na virada do século XVIII para o seguinte, ainda havia eruditos que, negando a legitimidade da nação, se criam partícipes de certa Internacional Aristocrática (Seillière 1903:XXXII). Se, por essa época, as então anacrônicas reivindicações de setores mais sectários da nobreza soavam como certo "canto do cisne", durante a voga conservadora que se seguiu à Restauração, em 1814, a controvérsia germanista foi retomada pelo Conde de Montlosier, porta-voz da nobreza contrarrevolucionária (Godechot 1961:11).

O universo de possibilidades objetivas de Montlosier tornava contraproducente, por um lado, insistir no vínculo entre seus correligionários legitimistas e aqueles supostos conquistadores francos - além das parcas referências históricas, um ataque frontal ao soberano poderia implicar o débacle da própria monarquia em um momento no qual estavam ainda em jogo alguns fundamentos das hierarquias tradicionais. Por outro, a conjuntura de guerras exaltara o sentimento nacional francês, inviabilizando o estabelecimento de uma ancestralidade exclusivamente germânica à nobreza que lhe era contemporânea. Não à toa, Montlosier substitui o vocábulo raça por povo - peuple double (Montlosier 1814-15:143-144). Menos importante do que insistir nas particularidades étnicas originais dos Estados era reconhecer que os verdadeiros franceses formavam um povo com características radicalmente distintas daquele que ele cria estrangeiro - o Terceiro Estado. A chave para a compreensão desse antagonismo irreconciliável pode ser encontrada no papel que Montlosier atribuía à família: era ela a unidade fundamental da nação francesa. Os indivíduos importavam pouco enquanto tais - eles eram, antes, membros de determinadas linhagens (Montlosier 1814-15:101). Daí seu olhar desconfiado aos constantes enobrecimentos, pois sob um título de nobreza subjazia uma concepção de mundo reproduzida geracionalmente. Ou seja, o conceito de povo mobilizado por Montlosier 
incorporava aquela comunidade de caracteres que Rémi-Giraud ressalta em sua definição de raça-linhagem. O recurso à ancestralidade permitia-lhe justificar as estratégias contrarrevolucionárias sustentando a necessidade histórica das hierarquias.

A ideologia germanista encerra uma reflexão que informou simultaneamente os pensamentos liberal e racialista do século XIX. No primeiro caso, uma vertente do germanismo cuja genealogia une Boulainvilliers, Montesquieu, Mably e Tocqueville; no outro, Boulainvilliers, DuBuat de Nançay, Montlosier e Gobineau. Em ambos, um legado intelectual estabelecido sobre uma tríplice identificação: no eixo negativo, centralização / igualdade / homogeneidade; no positivo, descentralização / liberdade / heterogeneidade.

Tocqueville é o último representante de um tipo de germanismo no qual a linhagem sucumbe em face da afirmação da nacionalidade e da substituição da rigidez da ordem hierárquica por certa flexibilidade característica das sociedades divididas em classes (Aron 1987:64). Em Gobineau, a incorporação da herança germanista torna a raça chave explicativa para a incomunicabilidade constitutiva das qualidades da nobreza. Ou seja, o primeiro incorpora o novo preceito burguês da igualdade entre os homens; o segundo reage à proclamação da igualdade buscando fundar alhures as eclipsadas distinções sociais particulares às sociedades divididas em ordens.

À burguesia vitoriosa importava despir o conceito de sua significação genealógica, isto é, daqueles elementos que outrora a associavam exclusivamente à noção de linhagem. Os herdeiros do abade Mably já haviam posto de lado o tema da guerra das raças, e a nação erguia-se sobre os preconceitos heráldicos. O moderno conceito burguês de raça repunha o tema da natureza. As diferenças raciais tornavam-se alvo de estudos empíricos voltados para a análise de traços fenotípicos. Nessa perspectiva, o nexo que indica Arthur Herman (1999) entre o recurso à temática racial e a filiação ao credo liberal apenas faz sentido quando referido àqueles teóricos que, ao contrário de Gobineau, despiram-se do tema da dualidade nacional. A raça biologizada não mais necessitava recorrer à história. Seus fundamentos eram observados no laboratório, não no recorrente ciclo histórico que, tal como revelado no Essai, conduzia as civilizações à derrocada.

Gobineau, não há dúvidas, foi um ferrenho adversário do liberalismo. Na aurora do século XIX, o pensamento liberal privilegiava o tema da autonomia individual e da perfectibilidade humana em detrimento daquelas noções que a subsumiam exclusivamente em mônadas coletivas, como a raça ou a família. Na segunda metade do século XIX, racialismo e liberalismo encontraram-se. Sob os escombros da raça-linhagem, ergueu-se aquela concepção de raça-espécie na qual desaparecia o tema familiar. Burgueses, 
afinal, não têm linhagem. O racialismo do fin-de-siècle renunciava ao tema da nação tal como esboçado pela nobreza querelante de outrora, e revigorado pelo erudito francês à sua época. Para essa tarefa, os "homens de ciência" do século XIX prescindiram de Gobineau.

O surgimento de uma concepção de raça-linhagem e sua posterior conversão em raça-espécie revela sob quais condições os homens começaram a pensar na existência de características que se transmitiriam geracionalmente no interior de determinados grupos. Em outras palavras, nas sociedades estavelmente hierarquizadas, a distinção entre os grupos é dada a priori. Porém, à medida que nelas penetram as reivindicações democráticas, o terreno torna-se fértil para a afirmação de novas formas de diferenciação. Em uma sociedade igualitária - no sentido tocquevilliano do termo - a distinção transfere-se, paulatinamente, para o campo da natureza. Conforme sugere Evans-Pritchard, "a proclamação da igualdade fez explodir um modo de distinção centrado no social, mas que misturava indistintamente aspectos sociais, culturais, físicos" (Evans-Pritchard apud Dumont 1992:314).

\section{O Tratado sobre as raças}

Na dedicatória do Essai, Gobineau apresenta a questão que orientava suas preocupações: quais as causas da agitação característica das épocas modernas (Gobineau 1983:136)? Na resposta à indagação, destaque ao elemento que, cria ele, explicava os reiterados fenômenos históricos de desenvolvimento e ruína das civilizações: os cruzamentos raciais.

O tratado é dividido em duas partes: na primeira, uma alentada exposição teórico-metodológica na qual ele explica os conceitos centrais que, por sua vez, serão "aplicados" na parte subsequente, composta pela história da criação e da ruína daquelas dez civilizações que, segundo Gobineau, mereceram, de fato, este epíteto: no velho mundo, as civilizações indiana, egípcia, assíria, grega, chinesa, romana e germânica; na América, as três grandes civilizações pré-colombianas.

O diplomata francês ficou conhecido como um crítico à miscigenação. Esta é uma meia-verdade que anuvia o "paradoxo trágico" (Taguieff 2002:51) no qual se encerra a pessimista filosofia da história gobiniana: como as raças têm qualidades distintas, é da contribuição de cada uma delas que advém o desenvolvimento civilizacional. Sem a mistura, os povos estariam condenados ao isolamento e limitados aos condicionamentos impostos por sua estreita constituição étnica. Mas com ela irrompe o princípio de dissolução inerente ao corpo social: a degeneração (Gobineau 1983:162-163). 
Uma civilização degenerada perde paulatinamente o vigor que outrora a caracterizava, levando à diluição irreversível do sangue dos fundadores, ou seja, de sua raça. Mas qual sentido conferia Gobineau a este conceito? Ele já se definira como "inimigo do século", e o tratado aponta para uma recusa radical da nova configuração política e ideológica da Europa moderna neste sentido, "sua hipótese [...] é mais social e política que propriamente biológica" (Banton 1979:57-58). Entretanto, o Essai não havia como deixar de ser, mesmo a contragosto, filho de seu tempo. O diplomata apropria-se pouco confortavelmente da hegemônica divisão tripartite entre os grupamentos humanos - branco, negro e amarelo — na busca de um fundamento universal determinante dos processos históricos (Gobineau 1983:280).

Gobineau vinculava o ímpeto civilizador menos à variação branca em sua totalidade do que a um ramo específico desta raça. Ele desejava ilustrar a importância da família ariana para o desenvolvimento das civilizações. Se iniciava seu estudo em busca da explicação das agitações contemporâneas, importava-lhe, sobretudo, narrar a epopeia dos arianos germânicos, fundadores da civilização ocidental.

Segundo o diplomata, os movimentos importantes da sociedade europeia tiveram sua origem na lenta introdução do elemento germânico nas camadas étnicas subjacentes. Assim como as demais grandes civilizações que povoaram o globo, ela se tornou merecedora desse epíteto porque, em sua gênese, encontrava-se aquela energia criadora singular à raça branca. Energia sempre paradoxal, que civiliza porque mistura e, por isso mesmo, leva à degeneração. Mas a ruína foi por vezes driblada através do afluxo de novas migrações arianas aptas a resgatar a vitalidade perdida. Desta feita, a moderna civilização que, segundo ele, em importantes aspectos superou as que lhe precederam (Gobineau 1983:299) vive seu irreversível crepúsculo (Gobineau 1983:1164).

O diplomata atribui exclusivamente à raça branca uma lei de atração que a impele à mistura (Gobineau 1983:167). Partidário da herança germanista, segundo a qual se atribui à nobreza o começo da corrupção (Boulainvilliers 1727:38; Tocqueville 1998:9), Gobineau, entretanto, a isenta de responsabilidade: atrelando o destino a ingredientes suposta e precariamente biológicos, a aristocracia torna-se inocente quanto à igualdade que, paradoxalmente, imprime ao mundo. Se a civilização realiza-se por meio da necessária miscigenação que, aos poucos, propaga a igualdade, o impulso civilizatório é próprio aos instintos das raças nobres — que não conhecem distinções entre os seus.

Gobineau pretendia estabelecer uma lei universal que explicasse a ascensão e a queda das civilizações. Pode-se sugerir que ele buscava esboçar um conceito de raça-espécie mas, para justificar seus argumentos, recorria a uma visão da decadência própria do universo da raça-linhagem. Com um 
vocabulário pretensamente contemporâneo, ele universalizava a crítica nobiliárquica ao Antigo Regime, corroborando a trajetória da história francesa mobilizada pelos opositores da potência monárquica durante a Querela, e personificada, em sua época - sob cores distintas, é verdade - na obra de seu amigo Tocqueville, O Antigo Regime e a revolução (Tocqueville 1897).

Tome-se como exemplo sua explicação para a ruína da civilização assíria, produzida pela mesma razão que lhe conferiu dinamismo: sua intensa vida mercantil. Por isso, lembrava Gobineau, não se deviam estabelecer relações necessárias de complementaridade entre a vitalidade de uma população e sua tendência ao comércio produtivo. As trocas não se limitavam aos produtos - o sucesso comercial abria as portas para as trocas étnicas.

À proporção que se intensificavam as misturas, elevavam-se as inclinações democráticas. A corrosão da ordem aristocrática iniciou-se na própria realeza, que já não guardava mais em suas veias o sangue de seus longínquos ancestrais. Em seguida, as reivindicações igualitárias encontraram eco entre "as massas turbulentas dos trabalhadores" (Gobineau 1983:397). Entretanto, "a revolução só triunfa quando nasce dos auxiliares que vivem no interior dos palácios nos quais ela se esforça para romper as portas" (Gobineau 1983:398), isto é, setores da nobreza empreenderam combates contrários aos seus próprios interesses. Nesta tarefa, foram paradoxalmente bem-sucedidos: ao fim e ao cabo, a nobreza sucumbiu plenamente, conforme Gobineau depreendia desse exemplo histórico.

No caso da civilização grega, ele afirma que, enquanto a linhagem permaneceu como o elemento definidor da hierarquia social, "nenhuma sombra de igualdade entre os outros ocupantes do solo e os mestres audaciosos" (Gobineau 1983:671), os arianos. Todavia, o apego à origem familiar sucumbia ante a lei de atração. A proibição dos cruzamentos era insuficiente para impedi-los. À medida que eles proliferavam, a legitimidade da interdição era colocada em cheque. As misturas que fundaram a Grécia semítica desenvolveram "a mais espiritual, a mais inteligente" (Gobineau 1983:93) habilidade artística jamais vista. Mas promoveram, igualmente, seus mais degradantes vícios.

A revogação da hereditariedade dinástica foi o principal sintoma da reviravolta étnica grega. Em uma sociedade racialmente estratificada, a escolha das lideranças era produto do acordo entre os elementos pertencentes ao segmento hierarquicamente superior - uma escolha entre iguais. À proporção que avançava a presença semita (populações mediterrâneas), a sociedade tornava-se cada vez mais heterogênea. Como escolher uma liderança comum aos diferentes (Gobineau 1983:693)? Segundo Gobineau, essa impossibilidade levou a civilização grega a criar a entidade fantasmagórica - a pátria. Para ele, subjazia-lhe um estado de confusão étnica somente compatível com um 
princípio de governo despótico. O absolutismo patriótico foi uma invenção semita cujo objetivo residia na ilusão de unificar instintos díspares.

Imagina-se, portanto, na Grécia, a criação de uma personagem fictícia, a Pátria, e ordena-se ao cidadão, por tudo aquilo que o homem pode imaginar de mais sagrado e de mais temível, pela lei, o preconceito, o prestígio da opinião, sacrificar em nome dessa abstração seus gostos, suas ideias, seus hábitos, até suas relações mais íntimas, até suas afeições mais naturais, e essa abnegação de todos os dias, de todos os instantes, foi a menor moeda dessa outra obrigação que consistia em dar, sob um indício, sem se permitir um murmúrio, sua dignidade, sua fortuna e sua vida logo que essa mesma pátria a demandava (Gobineau 1983:678-679).

Nos momentos subsequentes a tal criação, a força do elemento ariano era ainda suficientemente presente para garantir que os representantes supremos da pátria fossem, ao menos, selecionados no seio das mais nobres famílias. À medida que avançava a degeneração, tomavam corpo outros sintomas particulares aos momentos de anarquia étnica (Gobineau 1983:850): por um lado, a ascensão do dogma igualitário e sua correlata agenda reivindicatória, estopim de convulsões sociais. De outro, a prática centralizadora, que pretendia simplificar as relações políticas agrupando diferentes estados em apenas um.

Nos demais exemplos históricos narrados por Gobineau, reitera-se um modelo de decadência que retoma os argumentos da reação nobiliárquica que se opôs ao poder real durante a Querela das duas raças. Note-se que, não fosse a referência nominal à Grécia, a longa citação acima poderia facilmente ser confundida com as análises de Gobineau a respeito da recente história francesa (Gobineau 1928). Seu esforço erudito, ao invés de trazer um conteúdo novo à ideia de raça, mobilizava esse vocabulário, ainda precariamente biologizado, para renomear uma filosofia da história cujo vernáculo a Revolução de 1789 anacronizara.

\section{A concepção racial de Gobineau}

Até agora, pouco se disse sobre o conteúdo efetivo que o diplomata atribuía ao conceito de raça. O que significava, afinal, ser branco, negro ou amarelo? Na verdade, Gobineau não apresenta ao leitor uma definição precisa da ideia de raça (Banton 1979:54), limitando-se a alegar que, menos do que as características físicas, lhe importava investigar os efeitos morais dos condicionamentos étnicos. Mas, quando ele precisava os efeitos dos estímulos 
biológicos sobre o comportamento humano, apresentava uma caracterização que revelava o viés classista de sua definição de raça. Sugiro que a cada uma de suas raças correspondia um conjunto de disposições analiticamente associado à estratificação social presente no Antigo Regime francês: sua ficção histórica baseava-se em três raças/classes originais: negra/campesinato, amarela/burguesia, branca/aristocracia.

Aos negros ele destinava o último degrau em sua hierarquia racial. Isentos de miscigenação, jamais extrapolariam seu restrito círculo intelectual. A despeito da medíocre capacidade intelectiva, eles se destacavam pela ímpar intensidade no terreno das sensações - traço paradoxal, que estabelecia simultaneamente as razões de sua inferioridade e a principal contribuição da raça negra para o desenvolvimento das civilizações. Quando aliada ao elemento branco, essa tendência faz surgir a sensibilidade artística (Gobineau 1983:342). Para ilustrar a face negativa dessa "intensidade frequentemente terrível" (Gobineau 1983:340), Gobineau recorria rabelaisianamente ao tema da alimentação: "Todos os alimentos lhe são bons, nenhum o desagrada. O que ele deseja é comer, comer em excesso, com furor; não há carniça indigna de ser absorvida por seu estômago" (Gobineau 1983:340).

Esta descrição coaduna-se com uma caracterização recorrente daquilo que seria o comportamento padrão das populações camponesas. Na literatura, ela pode ser exemplificada pela obra de Rabelais, tal como revela Bakhtin (1996), à época de Gobineau, na descrição de Marx dos pequenos camponeses em O 18 Brumário (1974:277); nas ciências sociais contemporâneas, no conceito de gosto da necessidade, de Bourdieu (1979:435-448). ${ }^{10}$

Os amarelos são a antítese da raça negra: enquanto esta manifesta permanente passionalidade, aqueles privilegiam a dimensão utilitária, caracterizando-se por um desejo sóbrio e obstinado pelos prazeres materiais,

[...] em todas as coisas, tendência à mediocridade; compreensão bastante fácil daquilo que não é nem muito elevado ou profundo; amor ao útil [...]. Os amarelos são pessoas práticas no sentido estreito do termo. Eles não sonham, não apreciam as teorias, inventam pouco, mas são capazes de apreciar e adotar aquilo que os serve. Seus desejos se limitam a viver o mais doce e comodamente possível (Gobineau 1983:341).

Ora, não fosse a palavra amarelos, a citação poderia ter saído das páginas de A democracia na América, reforçando a hipótese segundo a qual a raça amarela representa, na ficção gobiniana, a burguesia ascendente que, sob a influência dos valores igualitários, prezava as "relações habituais [...] mais simples e mais cômodas" (Tocqueville 2000:209). 
O estudo de Tocqueville sobre os Estados Unidos foi citado no Essai uma única vez, em uma nota de rodapé (Gobineau 1983:207). Se as diferenças entre ambos saltavam aos olhos, as afinidades iam muito além do que poderia sugerir a parca referência em um pé de página. Herdeiros comuns do legado germanista, eles compartilhavam impressões sobre o caráter do homem burguês - que Gobineau insistia em chamar de amarelo.

No Essai, a civilização chinesa caracterizava-se por seu viés utilitário. Predominantemente amarela, ela devia a essa raça seu comum repúdio pelas teorias filosóficas abstratas. Se "não há, nos Estados Unidos, quase ninguém que se dedique à porção essencialmente teórica e abstrata dos conhecimentos humanos" (Tocqueville 2000:48), os chineses "amam a ciência no que diz respeito à sua aplicação imediata" (Gobineau 1983:588). Se os americanos não têm escola filosófica própria (Tocqueville 2000:3), na China "a filosofia, e sobretudo a filosofia moral, objeto de grande predileção, consiste apenas em máximas usuais" (Gobineau 1983:587).

Tanto no Novo quanto no Velho Mundo, um mesmo instinto utilitário mantinha a população imune às abstrações sediciosas tão particulares à França. Se Tocqueville explicava "por que os americanos nunca foram tão apaixonados quanto os franceses pelas ideias gerais em matéria política" (Tocqueville 2000:15), Gobineau assegurava que os chineses mantinham-se afastados das teorias socialistas (Gobineau 1983:591).

A analogia entre a raça branca e a aristocracia era imediata, afinal, sua superioridade étnica refletia-se em sua posição privilegiada na estrutura social. Brancos e amarelos compartilhavam certo senso de utilidade, mas os primeiros conferiam-lhe maior abrangência: seu instinto de ordem temperava seu gosto pronunciado pela liberdade. Daí advinha sua hostilidade em relação à organização formalista. Dado que os brancos são os únicos capazes de domar a lei de repulsão que interdita os cruzamentos, sobrepondo-lhe uma lei de atração que os impele ao contato com o diferente, foram exatamente seus pendores civilizatórios que os conduziram à quase extinção: seria em vão que se procuraria um legítimo representante da raça branca entre as atuais aglomerações mestiças (Gobineau 1983:281).

A fusão racial, portadora dos instintos igualitários, conduziu as civilizações pretéritas à anarquia étnica. Em momentos diversos, porém, a decadência estancou-se devido à entrada em cena de populações privilegiadas. Daí a particularidade dos novos tempos: desta feita, a heterogeneidade chegava a seu termo, decompondo até a neutralização definitiva os caracteres originais. Pela primeira vez na história da humanidade, o sangue ariano revelava-se estéril (Gobineau 1983:284), ou seja, as combinações étnicas agora irrefreáveis e unívocas unificaram aquilo que, nas sociedades precedentes, 
permaneceu múltiplo: a moderna civilização europeia transformou-se em um todo homogêneo. A era da unidade era a versão gobiniana para o fim da história (Gobineau 1983:1166).

Categoria moderna, a raça pertence paradoxalmente ao passado. Para o diplomata, a história do desenvolvimento das raças já atravessou três distintas fases: primária, secundária e terciária. Contemporaneamente, inaugura-se a etapa quaternária, na qual a ideia de raça perde sentido em face da anarquia étnica (Gobineau 1983:284). Ora, se mais acima foi sugerido que a hierarquia racial de Gobineau pode ser lida como uma metáfora sobre a estratificação social da sociedade francesa pré-revolucionária, pode-se sugerir que essa raça quaternária é provavelmente aquela classe exclusivamente moderna, brotada das entranhas da velha ordem: o proletariado. A irrupção da nova classe operária no cenário público traduz a impossibilidade de regeneração, afinal, "as condições de existência da velha sociedade já estão destruídas nas condições de existência do proletariado" (Marx \& Engels 1998:18).

Neste sentido, pode-se supor que sua verve fatalista reforçou-se durante as manifestações de junho de 1848, contribuindo decisivamente para a formulação das conclusões expressas no Essai. As jornadas revolucionárias, para ele, representavam "acontecimento sintomático da decadência da Europa" (Banton 1979:57). Observe-se que, se data de 1851 a primeira referência que Gobineau faz ao tratado, o testemunho de sua esposa assegura que a decisão de escrevêlo remonta a 1848 (Boissel 1993:110), mesmo ano no qual ele declara em seu poema Le roman de Manfredine: "Eu odeio mortalmente o poder popular [...]. Sim, o povo é estúpido" (Gobineau apud Gaulmier 1983:XXXI).

\section{Considerações finais}

O Essai inovava em sua conclusão. Na perspectiva racialista otimista, os valores da civilização triunfariam sobre todos; sua vertente pessimista afirmava a insociabilidade do selvagem: para preservar-se do contágio, condenava a miscigenação. Gobineau reescreveu o pessimismo: a mistura racial levaria à degenerescência da civilização. Esse processo irreversível estava já em estado avançado. Em outras palavras, aquele abastardamento dos poderes locais inscrito na história da formação do Estado moderno - a centralização — cumpriu sua obra: a vitalidade e a pluralidade singulares à organização hierárquica cederam seu espaço à ordem igualitária. Como notara Marx, "a burguesia rasgou o véu comovente e sentimental do relacionamento familiar" (Marx \& Engels 1998:10). Para Gobineau, esse longo processo, iniciado no seio da própria nobreza, anulou o valor das linhagens - por isso, não há retorno — afinal, 
[...] quando [...] o poder de fazer fortuna, de se ilustrar por meio de descobertas úteis ou talentos agradáveis, foi adquirido por todos, sem distinção de origem [...] a nação primitivamente conquistadora, civilizadora, começa a desaparecer (Gobineau 1983:169).

A teoria da miscigenação de Gobineau traduz uma resposta particular às crescentes reivindicações igualitárias que varreram o século XIX. O Essai reproduzia em tempos pretéritos a relativamente recente história francesa. Sua novidade consistia em extrair uma dinâmica de decadência que universalizava os argumentos que, na crítica da nobreza germanista, eram ainda predominantemente históricos. Dito de outro modo: ele narrava a glória e a ruína das civilizações resgatando passo a passo a crítica da reação nobiliárquica à formação da monarquia absoluta. A teoria racial de Gobineau atribuía um fundamento ontológico à centralização monárquica: tratava-se de um processo universal inscrito na lógica interna do movimento civilizacional. De certo modo, ele absolvia Henrique IV e seus sucessores. Até Richelieu tornava-se um fantoche guiado por uma lei natural. Não havia meios de resistir à lei da atração. A Revolução, afinal, já triunfara...

Recebido em 15 de dezembro de 2010

Aprovado em 14 de junho de 2011

Helga da Cunha Gahyva é professora adjunta do Departamento de Sociologia do IFCS/UFRJ. E-mail: < gahyva@superig.com.br>

\section{Notas}

* Título tomado de empréstimo do importante livro de Robert Dreyfus, indicado na bibliografia.

${ }^{1}$ A afirmação adquire consistência quando se constata o número expressivo de títulos que fazem referência ao estudo sobre as raças de Gobineau sem fornecer indicação correta quanto à sua data de publicação. Em 1954, Dante Moreira Leite (2002:442) assegurava que o tratado havia sido editado em 1854. Tanto Petrucelli (1996:134) quanto Ventura (1991:193) afirmam que sua publicação ocorreu em 1854. Schwarcz (1993:276), por sua vez, diz que o livro foi lançado em 1853, o que é verdadeiro somente quanto aos seus dois primeiros tomos. Segundo suas indicações bibliográficas, a autora parece 
crer tratar-se de obra em volume único, equívoco reiterado em trabalhos posteriores (2001:41; 1995:190). O descuido, porém, não é exclusividade nacional. Telles (2003:43) garante que o tratado data de 1856. Cf. também: Lester, P. \& Millot, J. 1936:212; Wieviorka 1991:230; Schure 1920:283. Ora, a ausência de um contato direto com a obra parece a óbvia explicação para o prosaico e reiterado engano. Segue-se daí a conclusão de que Gobineau vem frequentemente recebendo uma interpretação de segunda mão o que não raramente compromete a apreciação de suas ideias.

${ }^{2}$ Doravante denominado apenas Essai.

${ }^{3}$ Em 1884, o Essai seria enfim reeditado.

${ }^{4}$ Assume-se, neste artigo, a distinção estabelecida tanto por Todorov (1993:10) quanto por Taguieff $(2002: 17)$ entre racialismo e racismo. O primeiro equivale a uma formulação doutrinária, e apenas se torna racismo quando autoriza um programa político discriminatório. O racismo, em síntese, pode ser compreendido como uma variação comportamental da ideologia racialista. Nessa chave, a filosofia da história de Gobineau limita-se ao racialismo, pois seu tratado sobre as raças não fundava qualquer programa político - semelhante tentativa esbarraria na convicção primeira subjacente à obra: "a impossibilidade absoluta de reversão do declínio" (Taguieff 2002:36).

${ }^{5}$ Cumpre lembrar que, no Essai, Gobineau nega qualquer vínculo entre o herói ariano e o alemão contemporâneo. Essa convicção jamais o abandona. Décadas depois, em Ce qui se passe en Asie, ele reiterava: "Na França [...], o gênio germânico foi sufocado sob o número. A Alemanha não foi mais favorecida. [...] O sangue glorificado por Tácito não está então na Alemanha nem tão abundante nem tão difundido como se quis crer" (Gobineau 1928:25-16).

6 "A partir de 1933, é o racista que aparece à plena luz e não mais o 'agente' do estrangeiro" (Eugene 1998:226).

7 "Ainda que a palavra raça seja usada [...] de um modo compatível com as noções de distinções naturais, não tinha nesta altura quaisquer conotações biológicas" (Banton 1979:27).

${ }^{8}$ Se no Essai ele se mantém "próximo", quando analisada em conjunto, sua obra caminha na direção de uma adesão plena à noção de raça-linhagem, tal como expresso em seu derradeiro livro, Histoire de Ottar Jarl, pirate norvégien, conquérant du pays de Bray en Normandie et de sa descendance, publicado em 1879.

${ }^{9}$ Com esta expressão, Seillière não afirma a existência de uma organização feudal na França setecentista. Trata-se, ao contrário, de uma guinada nostálgica em direção à Idade Média, cujo ponto de partida é, exatamente, o desmantelamento das relações sociais que teriam caracterizado o período feudal. Para se referir a Boulainvilliers e seus pares, Guizot utiliza a expressão "publicistas feudais" (Guizot 1829-1832:2). Cassirer adota a expressão de Seillière: "Com intuito de provar as pretensões da nobreza francesa, Gobineau voltou a uma doutrina que havia sido 
proposta e defendida no século XVIII por Boulainvilliers e que tinha se tornado o fundamento da teoria do feudalismo" (Cassirer 1997:270).

${ }^{10}$ Deve-se ressaltar que as análises de Bahktin e Bourdieu referem-se às classes populares em geral, e não apenas à camponesa.

\section{Referências bibliográficas}

ARON, Raymond. 1987. As etapas do pensamento sociológico. Brasília: Ed. Universidade de Brasília.

AZEVEDO, Eliana. 1990. Raça: conceito e preconceito. São Paulo: Ática.

BAKHTIN, Mikhail. 1996. A cultura popular na Idade Média e no Renascimento: o contexto de François Rabelais. São Paulo: HUCITEC.

BANTON, Michael. 1979. A ideia de raça. Lisboa: Edições 70.

BELLESSORT, André. 1931. Les intellectuels et l'avênement de la Troisième République (1871-1875). Paris: Bernard Grasset.

BOISSEL, Jean. 1993. Gobineau: biographie (mythes et réalité). Paris: Berg International.

BOULAINVILLIERS, Henri de. 1727. Histoire de l'ancien gouvernement de la France: avec XIV lettres historiques sur les parlements où états généraux. Tome 1. La Haye: Aux Dépens de la Compagnie.

BOURDIEU, Pierre. 1979. La distinction: critique sociale du jugement. Paris: Les Éditions du Minuit.

CASSIRER, Ernst. 1997. El mito del Estado. Cidade do México: Fondo de Cultura Econômica.

DREYFUS, Robert. s.d. La vie et les prophéties du comte de Gobineau. Paris: Calman-Lévy.
DUMONT, Louis. 1992. Homo hierarchicus: o sistema das castas e suas implicações. São Paulo: EdUSP.

EUGENE, Eric. 1998. Wagner et Gobineau: existe-t-il un racisme wagnérien? Paris: Cherche Midi.

FOUCAUlT, Michel. 2002. Em defesa da sociedade: curso no Collège de France (1975-1976). São Paulo: Martins Fontes.

FURET, François. 1982. L'atelier de l'histoire. Paris: Flammarion.

GAULMIER, Jean. 1983. "Introduction". In: Arthur de Gobineau, Oeuvres. Tomo I. Paris: Gallimard. pp. IX-LVII.

GAY, Peter. 2001. O cultivo do ódio: a experiência burguesa da Rainha Vitória a Freud. São Paulo: Cia. das Letras.

GOBINEAU, Arthur de. 1928. Ce qui se passe en Asie et l'instinct révolutionnaire en France. Paris: Cahiers Libres. . 1983. "Essai sur l'inégalité des races humaines". In: Oeuvres. Tomo I. Paris: Gallimard. pp. 135-1174.

GODECHOT, Jacques. 1961. La contre-révolution: doctrine et action (1789-1804). Paris: Presses Universitaires de France.

GUIZOT, François. 1829-1832. Cours d'histoire moderne: histoire de la civilisation en Europe et en France. Paris: Pichon et Didier.

HERMAN, Arthur. 1999. A ideia de decadência na história ocidental. Rio de Janeiro: Record. 
LEITE, Dante Moreira de. 2002 [1954]. O caráter nacional brasileiro: história de uma ideologia. São Paulo: Ed. UNESP.

LESTER, P. \& MILLOT, J. 1936. Les races humaines. Paris: Armand Colin.

MABLY, Gabriel de. 1797. Observations sur l'histoire de France. Paris: Bossange/ Masson et Besson.

MARX, Karl. 1974. O 18 Brumário e cartas a Kugelman. Rio de Janeiro: Paz \& Terra.

. \& ENGELS, Friedrich. 1998. "Manifesto do Partido Comunista". In: Daniel Aarão Reis Filho (org.), O Manifesto Comunista 150 anos depois. Rio de Janeiro: Contraponto. pp. 7-41.

MONTLOSIER, François-Dominique. 1814-15. De la monarchie française depuis son établissement jusqu'à nos jours. Paris: H. Nicolle.

PETRUCCELLI, José Luis. 1996. “Doutrinas francesas e o pensamento racial brasileiro". Estudos, Sociedade e Agricultura, 7:134-149.

RAEDERS, George (org.). 1938. D. Pedro II e o Conde de Gobineau: correspondências inéditas. São Paulo: Cia. Editora Nacional.

REMI-GIRAUD, Sylvianne. 2003. "Le mot race dans les dictionnaires français du XIXe siècle". In: Sarga Moussa (dir.), L'idée de race dans les sciences humaines et la littérature (XVIIe et XIX siècles): actes du colloque international de Lyon (16-18 novembre 2000). Paris: L'Harmattan. pp. 203-221.

ROUAULT, Joseph-Marie. 1943. La Troisième République vue par le Comte de Gobineau. Paris: Mercure de France.

SCHWARCZ, Lilia Moritz. 2001. "Dando nome às diferenças". In: Eni de Mesquita Samara (org.), Racismo \& racistas: trajetória do pensamento racista no Brasil. São Paulo: Humanitas/FFLCH/ USP. pp. 9-43.
. 1995. "Nomeando as diferenças: a construção da ideia de raça no Brasil". In: Gláucia Villas Bôas (org.), O Brasil na virada do século: o debate dos cientistas sociais. Rio de Janeiro: Relume-Dumará. pp. 177-191. . 1993. O espetáculo das raças: cientistas, instituições e questão racial no Brasil - 1870-1930. São Paulo: Cia. das Letras.

SCHURE, Edouard. 1920. Précurseurs et révoltés. Paris: Perrin \& Cia.

SEILLIÈRE, Ernest. 1903. Le comte de Gobineau et l'arianisme historique. Paris: Plon.

TAGUIEFF, Pierre-André. 2002. La couleur et le sang: doctrines racistes à la française. Paris: Mille et Une Nuits.

TELLES, Edward. 2003. Racismo à brasileira: uma nova perspectiva sociológica. Rio de Janeiro: Relume-Dumará

THIERRY, Augustin. 1840. Considérations sur l'histoire de France: récits des temps mérovingiens. Paris: J. Tessier.

TOCQUEVILLE, Alexis de. 2000. A democracia na América: sentimentos e opiniões. São Paulo: Martins Fontes. .1998. A democracia na América: leis e costumes. São Paulo: Martins Fontes. . 1897. O Antigo Regime e a Revolução Brasília: Ed. Universidade de Brasília.

TODOROV, Tzevetan. 1993. Nós e os outros: a reflexão francesa sobre a diversidade humana. vol. 1. Rio de Janeiro: Jorge Zahar.

VENTURA, Roberto. 1991. Estilo tropical: história cultural e polêmicas literárias no Brasil (1879-1914). São Paulo: Cia. das Letras.

WIEVIORKA, Michel. 1991. L'espace du racisme. Paris: Editions du Seuil. 


\section{Resumo}

O presente artigo discute a concepção racial de Arthur de Gobineau a partir de sua mais famosa obra, o Essai sur l'inégalité des races humaines. Se comumente este tratado é associado à discussão racialista que toma corpo nas últimas décadas do século XIX, pretendo relacioná-lo a uma polêmica característica da virada do século XVII para o XVIII, a Querela das duas raças. Neste sentido, o objetivo do artigo é revelar, em primeiro lugar, como a reflexão de Gobineau é tributária de um conceito de linhagem tornado paulatinamente anacrônico no mundo pós-revolucionário. Em segundo, demonstrar a hipótese segundo a qual o Essai, menos do que um estudo sobre raças pretensamente "biológicas", representa fundamentalmente uma recusa à nova ordem igualitária que se impõe na era moderna.

Palavras-chave Pensamento Conservador, Século XIX, Racialismo, Igualdade, Modernidade.

\section{Abstract}

The present article discusses the racial concepts of Arthur de Gobineau based on his most famous work, Essai sur l'inegalité des races humaines. Instead of associating these with the racialist debate of the last decades of the XIX the century, I relate them to a polemical text characteristic of the late XVII and early XVIII century: The Quarrel of the Two Races. In this sense, my main objective is to show that, in the first place, the Gobineau's work owes significant debts to the concept of the "bloodline", an idea which gradually became anachronistic after the French Revolution. In addition, I argue that, rather than being a study of supposedly "biological" races, Gobineau's "Essay" should be regarded as a refusal of the new egalitarian order of modern times.

Key words Conservative thought, $19^{\text {th }}$ Century, Racialism, Equality, Modernity. 